www.jmscr.igmpublication.org

Index Copernicus Value: 79.54

ISSN (e)-2347-176x ISSN (p) 2455-0450

crossref DOI: https://dx.doi.org/10.18535/jmscr/v7i5.106

Journal Of Medical Science And Clinical Research

IGM Publication

An Official Publication of IGM Publication

\title{
Effectiveness of Guidance Programme on Impact of Parental Alcoholism among Adolescents in Selected Schools, Mangaluru: A Pilot Study
}

\author{
Authors \\ Prof. Greesha Jose ${ }^{1}$, Dr Veena Gretta Tauro ${ }^{2 *}$ \\ ${ }^{1}$ Vice Principal,Tejasvini College of Nursing, Mangaluru, Karnataka, India \\ ${ }^{2}$ Masood College of Nursing, Mangaluru, Karnataka, India \\ *Corresponding Author \\ Dr Veena Gretta Tauro \\ Masood College of Nursing, Mangaluru, Karnataka, India
}

\begin{abstract}
Alcohol consumption is the greatest risk factor for the disease and disabilities in the middle income and the third highest in the world. The children commissioner's reported that should have rapid evidence assessment of the needs and experience of children for the parental alcohol misuse and exploration. The present pilot study aimed to assess the Effectiveness of guidance programme on impact of parental alcoholism among adolescents in selected schools, Mangaluru. An evaluative approach with one group pretest post test was found to be appropriate for assessing the effectiveness. The Boys and girls aged $12-15$ years screened with Children of Alcoholics Screening Test. 35 adolescents were pretested with Rosenberg self esteem scale, Family interaction pattern scale, security inventory rating scale and coping check list. Face to face guidance program was implemented; post test was done by using same instruments. The results revealed that the guidance programme was effective in increasing self esteem (t35 11.23352. $p<.05$ ), improving family interaction(t35 5.06159. $p<.05)$, increased sense of security feeling(t35 5.28853. $p<.05)$ and increased level of coping( t35 $2.55403 p<.05)$. There was strong positive correlation found between self esteem and family interaction pattern $(r=0.9012 p<.05)$. There was no association found between selected demographic variables with self esteem, level of family interaction and level of coping. The study concluded that guidance program helped to improve the adolescent's self esteem, family interaction, security feeling and adaptation.
\end{abstract}

Keywords: adolescents, alcoholic parent, self esteem, family interaction, security feeling, coping, guidance progamme.

\section{Introduction}

Adolescence is the developmental phase of life stretching between childhood and adulthood, encompasses with biological growth and major social role transitions ${ }^{1}$. They outline a new identity against the image of the adult along with the acceptance of social group norms retrieved from the peer group ${ }^{2}$ 
Alcoholism is a disease of the family because it affects the entire family members ${ }^{3}$. Most of the parents expect that their children have the capacity to determine the proper boundaries of alcohol use, regardless what they modelled from a parent. Unfortunately, an adolescent's future relationship with alcohol is cultivated in the home. Parents who use alcohol directly preparing setting to raise an adolescent become an alcoholic ${ }^{4}$.

In southern India, the prevalence of current alcohol use is said to vary between $33 \%$ and 50\% depending on probably education and poverty. Research indicates that harmful use of alcohol causes approximately 3.3 million deaths every year(5.9\% of all deaths) globally, and the alcohol consumption attributes $5.1 \%$ of the global burden of disease $\mathrm{s}^{5}$. The average age of initiating drinking was $23.63 \pm 6.01$ years which is higher $(20.8 \pm 5.9$ years) than from Kolkata ${ }^{6}$. In Bengaluru $52 \%$ of the people were consuming alcohol inorder to lighten pain and induce sleep ${ }^{7}$. Study from southern Karnataka reported that nearly $38.1 \%$ of men between 16 years to 49 years of age had an alcoholic habit ${ }^{8}$. Researches from Udupi, Karnataka have shown that $17.8 \%$ of illiterates above 15 years are alcohol and tobacco users. ${ }^{9,10}$ The prevalence of current alcohol use in Southern India has varied between $33 \%$ and $50 \% .^{11}$

The home environment matters a lot in self esteem development of an adolescent. The alcoholic home environment very often has a negative impact on the child's emotional development and later adjustment. The acquisitions of healthy feelings of self esteem are not consistently present. $^{12}$

Uses of alcohol not only affect the person drinking, but everyone around them especially the adolescent in the family. There will be financial problems, family conflict violence and mood swings. It can leads to feelings of fear, anxiety, loneliness embarrassment, guilt and shame. They end up in low self esteem, depression suicidal thoughts and substance abuse ${ }^{13}$.

Parental alcohol abuse puts adolescents at greater risk for having intellectual, physical social and emotional problems than peers ${ }^{14}$. The parental alcoholism does create hindrance in the effective psychosocial functioning of the adolescent children. Adult children of alcoholics are also more likely to abuse substances and are significant risk in developing substance abuse ${ }^{15}$ and those with insecure attachment have been found greater risk in developing psychopathological problems in adulthood $^{16}$

Keeping in the view the alarming increase of alcoholism in our society, the need for understanding and helping the growing adolescent children of alcoholic parent, the researcher attempts to explore the impact of parental alcoholism on self- esteem, family interaction, security feeling and level of coping of the adolescent. The guidance programme will ensure the adolescent to lead a better strategy and adopt a coping behaviour in their life thus building a good generation.

\section{Materials and Methods}

One group pretest post test, evaluative approach was used in the study. In the first phase of study adolescents from selected schools were screened by Children of Alcoholics Screening Test to identify the adolescents of alcoholic parent 35 adolescents aged 12 years -15 years both boys and girls studying in selected schools of Mangaluru were selected by purposive sampling. Those were pretested with Rosenberg's self esteem scale, family interaction pattern scale, security inventory scale and coping check list. A guidance program was implemented with motivational technique. Researcher spends 30 minutes with each adolescent for 3 sessions followed by post test. 


\section{Results}

Table I: Description of the demographic variables of the adolescents of alcoholic parents

\begin{tabular}{|c|c|c|c|}
\hline Sl no & Demographic Variables & Frequency & Percentage \\
\hline 1 & 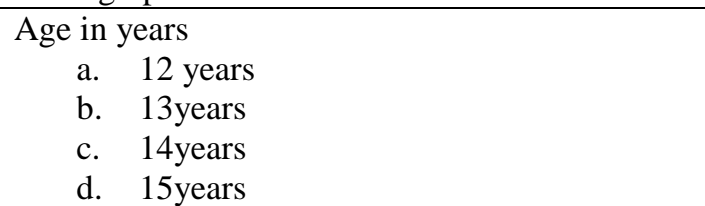 & $\begin{array}{c}9 \\
6 \\
9 \\
11\end{array}$ & $\begin{array}{l}25.72 \\
17.16 \\
25.72 \\
31.42\end{array}$ \\
\hline 2 & \begin{tabular}{lc}
\multicolumn{2}{l}{ Gender } \\
a. $\quad$ Male \\
b. Female
\end{tabular} & $\begin{array}{l}13 \\
22\end{array}$ & $\begin{array}{l}37.14 \\
62.86\end{array}$ \\
\hline 3 & \begin{tabular}{ll}
\multicolumn{2}{l}{ Religion } \\
a. & Hindu \\
b. & Christian \\
c. & Muslim \\
d. & any other
\end{tabular} & $\begin{array}{c}20 \\
15 \\
0 \\
0\end{array}$ & $\begin{array}{c}57.14 \\
42.86 \\
0 \\
0\end{array}$ \\
\hline 4 & $\begin{array}{l}\text { Type of family } \\
\text { a. nuclear } \\
\text { b. joint } \\
\text { c. any other }\end{array}$ & $\begin{array}{c}27 \\
1 \\
7\end{array}$ & $\begin{array}{c}77.14 \\
2.86 \\
20.00\end{array}$ \\
\hline 5 & 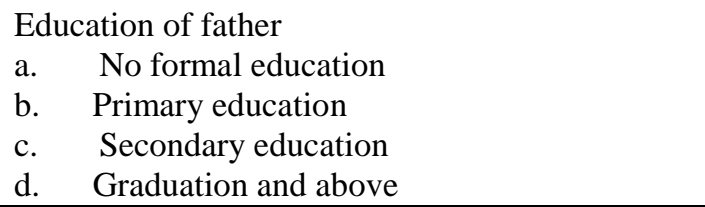 & $\begin{array}{c}2 \\
5 \\
21 \\
7\end{array}$ & $\begin{array}{c}5.71 \\
14.29 \\
60.00 \\
20.00\end{array}$ \\
\hline 6 & \begin{tabular}{ll}
\multicolumn{2}{l}{ Education of mother } \\
a. & No formal education \\
b. & Primary education \\
c. & Secondary education \\
d. & Graduation and above
\end{tabular} & $\begin{array}{c}5 \\
14 \\
16 \\
0\end{array}$ & $\begin{array}{c}14.29 \\
40.00 \\
45.71 \\
0\end{array}$ \\
\hline 7 & $\begin{array}{l}\text { Among your parent/s who uses alcohol } \\
\text { a. Father } \\
\text { b. Mother } \\
\text { c. Both }\end{array}$ & $\begin{array}{c}22 \\
3 \\
10\end{array}$ & $\begin{array}{c}62.86 \\
8.57 \\
28.57 \\
\end{array}$ \\
\hline 8 & $\begin{array}{l}\text { Describe the alcohol use pattern of parent } \\
\text { a. Father } \\
\text { a. Daily Drinker } \\
\text { b. Regular Weekend drinker } \\
\text { c. Occasional drinker } \\
\text { d. Social drinker } \\
\text { b. Mother } \\
\text { a. Daily Drinker } \\
\text { b. Regular Weekend drinker } \\
\text { c. Occasional drinker } \\
\text { d. Social drinker }\end{array}$ & $\begin{array}{c}30 \\
0 \\
0 \\
2 \\
\\
8 \\
0 \\
5 \\
0\end{array}$ & $\begin{array}{c}93.75 \\
0 \\
0 \\
6.25 \\
\\
61.54 \\
0 \\
38.46 \\
0\end{array}$ \\
\hline 9 & $\begin{array}{l}\text { Duration of alcohol drinking habit of your parent } \\
\text { (-----in years ) }\end{array}$ & & \\
\hline & $\begin{array}{l}\text { father } \\
<5 \text { year } \\
\text { 06years }-10 \text { years } \\
11 \text { years }-15 \text { years } \\
>16 \text { years } \\
\text { Mother } \\
<5 \text { year } \\
\text { 06years }-10 \text { years } \\
11 \text { years }-15 \text { years } \\
>16 \text { years }\end{array}$ & $\begin{array}{c}1 \\
7 \\
17 \\
7 \\
\\
0 \\
13 \\
0 \\
0\end{array}$ & $\begin{array}{c}3.13 \\
21.87 \\
53.13 \\
21.87 \\
0 \\
100 \\
0 \\
0 \\
\end{array}$ \\
\hline
\end{tabular}




\begin{tabular}{|l|l|c|c|}
\hline 10 & Your happiness is being part of your family & & \\
& a. To a great extent & 5 & 14.29 \\
& b. To some extent & 4 & 11.43 \\
& c. Cannot say & 2 & 5.71 \\
& d. Not at all & 24 & 68.57 \\
\hline 11 & Use of any other substances in your parent & & \\
& a. Father $\quad$ No & 21 & 60 \\
& Yes & 14 & 40 \\
\cline { 2 - 4 } & Mother & & \\
& b. No & 13 & 100 \\
\hline
\end{tabular}

Demographic variables of the subject shown that majority of the adolescents were in 15 years $(31.42 \%)$ of age, 14 years were $(25.72 \%), 13$ years were $(17.16 \%)$, and 12years $(25.72 \%)$. $62.86 \%$ were girls and majority of the subject belongs to nuclear family(77.14\%).

In relation to the parental alcoholism, $62.86 \%$ of the drinkers were fathers, $8.57 \%$ were mothers and $28.57 \%$ both parents were alcoholics. Among fathers majority $(93.75 \%)$ of them were daily drinker and $61.54 \%$ of the mothers were daily drinker. $53.13 \%$ of the fathers and all the mothers were daily drinkers. $40 \%$ of the fathers had the habit of using other substances with alcohol such as smoking and chewing.

Majority $(67.57 \%)$ of the adolescents were not all happy as being part of their family. $11.43 \%$ were to some extend happy and $14.29 \%$ were happy as being part of their family to great extent.

Table 2: overall mean, SD and t test of pretest and post test of guidance programme

\begin{tabular}{|l|c|c|c|}
\hline Variables & Mean SD & 't' value & P value \\
\hline Self esteem & $4.71 \pm 5.10$ & 11.23352 & $<.00001^{*}$ \\
\hline Family interaction & $19.97 \pm 8.01$ & 5.06159 & $<.00001^{*}$ \\
\hline Security feeling & $40 \pm 12.63$ & 5.28853 & $<.00001^{*}$ \\
\hline Level of coping & $5.37 \pm 3.13$ & 2.55403 & $<.00001^{*}$ \\
\hline
\end{tabular}
$\mathrm{df}=34, \mathrm{p}<0.05 .{ }^{*}$ Significant

Inferential statistics was used to compute the effectiveness of guidance program. The $t$ test revealed that the guidance programme was effective in increasing self esteem ( $t_{35}$ 11.23352. $\mathrm{p}<0.05)$, improving family interaction $\left(\mathrm{t}_{35}\right.$ 5.06159. $\mathrm{p}<0.05)$, increased sense of security feeling $\left(\mathrm{t}_{35}\right.$ 5.28853. $\left.\mathrm{p}<0.05\right)$ and increased level of coping $\left(\mathrm{t}_{35} 2.55403 \mathrm{p}<0.05\right)$.

Pearson correlation coefficient was computed to find correlations between the variables. There was strong positive correlation found between self esteem and family interaction pattern $(r=0.9012$ $\mathrm{p}<.05)$. A weak positive correlation found between self esteem and security feeling ( $\mathrm{r}=$ $0.1862 \mathrm{p}<.05)$ and self esteem with coping $(\mathrm{r}=$ $0.1556 \mathrm{p}<.05)$.

There was no association found between selected demographic variables with self esteem, level of family interaction and level of coping. The study concluded that guidance program helped to improve the adolescent's self esteem, family interaction, security feeling and adaptation

\section{Conclusion}

Alcoholism is called as a family disease, because one person's addiction leads to complete family dysfunction. Adolescents in the family develops low self esteem, unhealthy family interaction, low security feeling and maladaptation towards the alcoholic patent because of social rejection and aloofness. This pilot study revealed that adequate support and guidance will increase the self esteem, family interaction, security feeling and adaptive coping; being an adolescents of alcoholic parent. 


\section{References}

1. Susan M Sawyer, Peter S Azzopardi, Dakshitha Wickremarathne, George C Patton. The age of adolescence. The lancet child and adolescent health; vol. 2(3), pp. 223-228,2018

2. Ioana Ancuta Fran. Implications Of SelfEsteem In Adolescence, Journal Plus Education, XIV (1),pp. 90-99, 2016

3. Crnkovic A, Elaine, Delcampo, Robert L. A Systems Approach to the Treatment of Chemical Addiction, Contemporary Family Therapy, Volume 20, Issue 1, pp 25-36, March 1998,

4. Laura Nott. Impact of Alcoholic Parents on Teens with Substance Abuse Problems, Elements of behavioural health, 2013

5. Girish N, Kavita R, Gururaj G, Benegal V. Alcohol use and implications for public health: Patterns of use in four communities. Indian J Community Med, vol. 35, pp.238-44, 2010

6. Ghosh S, Samanta A, Mukherjee S. Patterns of alcohol consumption among male adults at a slum in Kolkata, India. J Health Popul Nutr vol.30, pp.73-81, 2012.)

7. John A, Barman A, Bal D, Chandy G, Samuel J, Thokchom M, et al. Hazardous alcohol use in rural Southern India: Nature, prevalence and risk factors. Natl Med J India vol. 22, pp.123-5, 2002.

8. Daniel AB, Nagaraj $K$, Kamath R.Prevalence and determinants of tobacco use in a highly literate rural community in southern India, Natl Med J India, vol. 21(4), pp.163-5, Jul-Aug2008

9. Reddy KS, Perry CL, Stigler MH, Arora M. Lancet, Differences in tobacco use among young people in urban India by sex, socioeconomic status, age, and school grade: assessment of baseline survey data,vol. 367(9510), pp.589-94, 2006 Feb 18

10. India National Family Health Survey (NFHS-3), 2005-2006. International Institute for Population Sciences; 2007

11. WHO Expert Committee on Problems Related to Alcohol Consumption: Second Report. WHO Regional Office for the Western Pacific; 2007

12. Dawn Clancy. Characteristics of Adult Children of Alcoholics, feature news from The fix addiction and recovery straighten up, 2015

13. The National Association for Children of Alcoholics, Breakthrough! Government Launches 'Innovation Fund' for Children of Alcohol Dependent Parents, April 2018

14. Carissa Lawrence. The effects of parental alcohol abuse on children, 2017 https:// healthfully.com > Family Health

15. Stone AL, Becker LG, Huber AM, Catalano RF. Review of risk and protective factors of substance use and problem use in emerging adulthood. Addict Behav;37(7), pp.747-775, 2012

16. Ewa Wyrzykowska, Karolina Głogowska, Kinga Mickiewicz. Attachment relationships among alcohol dependent persons. Alcoholism and Drug Addiction; 27(2), pp.145-161, 2014. 